\title{
Supporting Indicators for the Successful Solid Waste Management Based on Community at Rawajati, South Jakarta
}

\author{
Muhammad Furqan' \\ Kementerian Pekerjaan Umum \\ DKI Jakarta, Indonesia
}

\begin{abstract}
Community-based waste management is one of the strategies that can be used to overcome the problems of garbage that exist today. However, community-based waste management system could not be implemented as a whole in Indonesia and sometimes some areas are trying to do community-based waste management do not work well and is not sustainable. The purpose of this study was to determine the indicators of success in supporting community-based waste management in Urban Rawajati RW III, South Jakarta. The method of analysis used in this study using quantitative descriptive analysis, and discriminant analysis are useful for describing indicators supporting the success and sustainability of community-based waste management in RW III. Supporting indicators of success in community-based waste RW III, Sub Rawajati divided into 2 main indicators and supporting indicators. The main indicator of success is the use of RW III inorganic waste, the amount of participation, ownership and use of grinding machine home composter are classified into two major variables, namely the participation of society and shape the technology, while the supporting indicators are classified into three variables, namely institutional agreements, operational management and management financially.
\end{abstract}

Keyword: waste management, community based, rawajati

\section{Background}

The existence of community-based waste management could be one way to reduce the problems caused by litter. Community-based waste management system requires the society to be more aware of the waste around their environment, especially the waste generated by each individual. Caring of waste are intimately associated with the concept of community-based waste management. Community-based waste management requires further management of waste generated by sorting, composting, and 3R (Reuse, Recycle, Reduce). 3R concept will support the reduction in the quantity of waste at the level of the community that have an impact on the amount of waste going into landfills appointed (Sivaranjani, 2000).

In other side, a community-based waste management sometimes cannot be applied in every area. Community-based waste management in developing countries like India cannot survive due to declining participation, the absence of a clear social organization, lack of support and others (Joseph, 2005). Many areas are trying to replicate the

\footnotetext{
${ }^{1}$ Korenspondensi Penulis: Kementerian Pekerjaan Umum, DKI Jakarta

Email: furqonmuhammad27@yahoo.com
} 
community-based waste management in order to handle the waste problem in their neighborhood, but many of them are stopped in the middle of the programs or run imperfectly. In addition, there are several areas that show successful implementation of community-based waste management. The failure process of community-based waste management in some areas can be influenced by many reasons such as internal and external causes.

In some areas, society makes their own association to initiate community-based management activities and often the assembly received financial assistance from the local government. Unfortunately, despite trying to do a community-based waste management system they are sometimes not properly working either being sustainable. While in some areas there is a successful waste management. The existence of this phenomenon became the object of interest for further discussion and raises the question 'what indicators are supporting the successful and sustainable community-based waste management in some areas?'

\section{Regional Scope}

The scope of this research area is a place or area that has community-based waste management. Community-based waste management referred in this research is a waste management which involves a community or society in their wasting process (sorting, collecting, and processing waste)so that it could reduce the amount of waste to be transported to landfills. Besides relying on the community to process waste such as sorting and doing composting, the community is also relied upon to carry out a proper waste management. This waste management can include institutional processes, conduct participation, financing, and also participating in the agreement if it existed.

For example the successful waste management system is in the RW III Rawajati Village, South Jakarta which has a nice green environment. The green-neighborhood concept was their first main idea in creating the system in RW III. Due to the shortage of compost for their green-neighborhood programs, so they initiate to creating their own compost. Started from sorting the organic and an-organic waste from the neighborhood, and now they are running the communal waste management RW III. Compared to other village, RW III hasmore social activities especially in handling their own waste. Not a few different groups of people and institutions come to RW III for training both in the processing of organic and non-organic waste and the composting. RW III is not only known as a pilot of waste management and processing good compost, but also famous for its green-neighborhood in the region to creating the impression of comfort and beauty settlement. This green project was conducted jointly by the community at RW III as a form of concern for the environment.

\section{Supporting Indicators of The Successful Waste Management}

To make the community-based waste management works, it is needed to reinforce the components of the waste itself. One of the way that can be used to make it works is designing the community system of waste management approach. With a design, itpractically will form a successful waste management. At the end, the design approach itself can be used to determining the supporting indicators of successful waste management adopted from Ashok, 2009, which is used to approach the supporting factors in the successful of community-based waste management. In general Ashok, 2009 explains there are five major variables that need attention so that we can be determine the indicators 
Table 1. The Supporting Indicators of Successful Waste Management

\begin{tabular}{|c|c|c|}
\hline No & Criteria & Explanation \\
\hline \multirow[t]{2}{*}{1} & \multicolumn{2}{|l|}{ Community Participation } \\
\hline & Participation Form & $\begin{array}{l}\text { Forms of participation can be seen from how } \\
\text { the community in managing the waste as the } \\
\text { waste sorting, composting home scale or } \\
\text { manufacturing recycled systems }\end{array}$ \\
\hline \multirow[t]{3}{*}{2} & \multicolumn{2}{|l|}{ Adjustment Technology } \\
\hline & Forms of Waste Transportation & \multirow[t]{2}{*}{$\begin{array}{l}\text { See where is the grinding machines and the } \\
\text { use of home composter }\end{array}$} \\
\hline & Composting management form & \\
\hline \multirow[t]{3}{*}{3} & \multicolumn{2}{|l|}{ Operational Management } \\
\hline & $\begin{array}{l}\text { Forms of } \quad \text { Waste } \\
\text { Transportation }\end{array}$ & $\begin{array}{l}\text { The form transporting waste can be seen from } \\
\text { the transportation of household } \\
\text { waste into TPST and then to landfill }\end{array}$ \\
\hline & Composting management form & $\begin{array}{l}\text { It can be seen from the availability of } \\
\text { composting which conduct by their society }\end{array}$ \\
\hline \multirow[t]{3}{*}{4} & \multicolumn{2}{|l|}{ Financial Management } \\
\hline & Financing form & $\begin{array}{l}\text { Financing for community-based waste } \\
\text { management can be collected by a } \\
\text { voluntary contributions, a compulsive } \\
\text { contributions or a deposit from the } \\
\text { proceeds of waste management }\end{array}$ \\
\hline & Financing from related parties & $\begin{array}{l}\text { Measurement of variables related to } \\
\text { financing can be seen from either the } \\
\text { donations of goods or materials that can } \\
\text { support the management of waste } \\
\text { obtained from NGOs or government }\end{array}$ \\
\hline \multirow[t]{2}{*}{5} & Institutional Agreement & \\
\hline & Form of Agreement & $\begin{array}{l}\text { Form of agreement is one of the requirements } \\
\text { made in waste management. Forms of this } \\
\text { agreement can be seen from the creation of an } \\
\text { agreement between the management of waste } \\
\text { management with local government agencies } \\
\text { or NGOs that helped build a successful waste } \\
\text { management }\end{array}$ \\
\hline
\end{tabular}

\section{Identifier Analysis of Community-Based Waste Management Success In RW III, Village Rawajati}

In a community-based waste management there are many indicators to make it success. We used 68 respondents that separate in 3 group to analyze solid waste management based on community in RW III, South Jakarta. The first group is the people who work (Success), the second is the people who doubting their success and the third is a society that did not work (Didnt Success). To perform discriminant analysis we need many indicators (see tabel 1) for selecting what the strongest indicator that can make identifier in every group. These indicators derived from Ashok, 2010 with modify for Solid Waste Management based on community in RW III, South Jakarta. Some indicators are modified is the amount of participation, forms of waste transportation, cooperation and etc. After discriminant analysis, obtained from the discriminant function to determine the identifier of the people who succeed in doing community-based waste management and who do not succeed in doing community-based waste management. The discriminant equation that emerges is as follows. 


$$
\begin{aligned}
Z \text { score } 1 & =-0,084 X_{5}+0,501 X_{50}-0,347 X_{22}+0,489 X_{33} \\
Z s c o r e 2 & =-0,956 X_{5}+0,371 X_{50}+0,872 X_{22}-0,097 X_{33}
\end{aligned}
$$

Description:

X5 = Public Participation In an-organic Rubbish

X50 $=$ Presence Grinder Machine

$\mathrm{X} 22=$ Mount of Participation

X33 = Ownership of Home Composter

Overall it can be seen that among the many indicators there are four indicators that determine the success or failure of community-based waste management in RW III, Village Rawajati. Based on the results of discriminant analysis, there are four indicators that affect the succes solid waste management based community in Rawajati, they are the utilization of inorganic waste, the amount of community participation, ownership of a home composter and role of grinding machines in TPST. After reviewing of the case is quite reasonable because all four of these indicators have a very important role. Determinants of successful community group or not in the discriminant analysis only used four indicators of 12 indicators, this is because the eight indicators just do not have enough significant differences to determine the classification of a group of successful and unsuccessful.

There are 2 of the most influential indicators from 4 indicators that explain before to support the success of community-based waste management in RW III. Both of these indicators is the presence and use of grinding machines as well as ownership of the home composter. In general it can be seen from the existing data that a successful community group changes into society and do not hesitate successfully determined by both indicators. Initial allegations are people who managed to trash the election, but after discriminant analysis and cross-checking with existing data that success is also determined by the use of grinding machines as the most important indicator, the participation of inorganic waste, the amount of participation as well as ownership home composter. This is because of each of these indicators have a significant role in supporting the success of waste management in RW III, as support decreased the amount of waste, can increase public awareness and motivate people to continue to participate, while the change from managed to free-tend to doubt the strongest indicator is home composter ownership. It is quite reasonable because the home composter significant role in the processing of organic waste. When viewed as a whole that these four indicators focusing on the aspect of waste management in which people are required to do the sorting and composting also do either at home or in communal waste management

\section{Conclusion}

There are 4 important indicators to define the SuccessSolid waste management in RW III, Rawajati, South Jakarta. Such as the participation of inorganic waste utilization, the number of community participation, home composter ownership and role of composter mill waste as four strong indicators to support the success of solid waste management in RW III. The other indicators as supporting indicator for success in solid waste management based on community in RW III, Rawajati, South Jakarta. Four main indicators got from discriminant analysis are the strongest identifier to define the success of solid waste management in RW III, Rawajati South Jakarta. These indicators divide as two big group variable, the first variable is people participation and Technology form for second variable that explained by Ashok, 2009. 

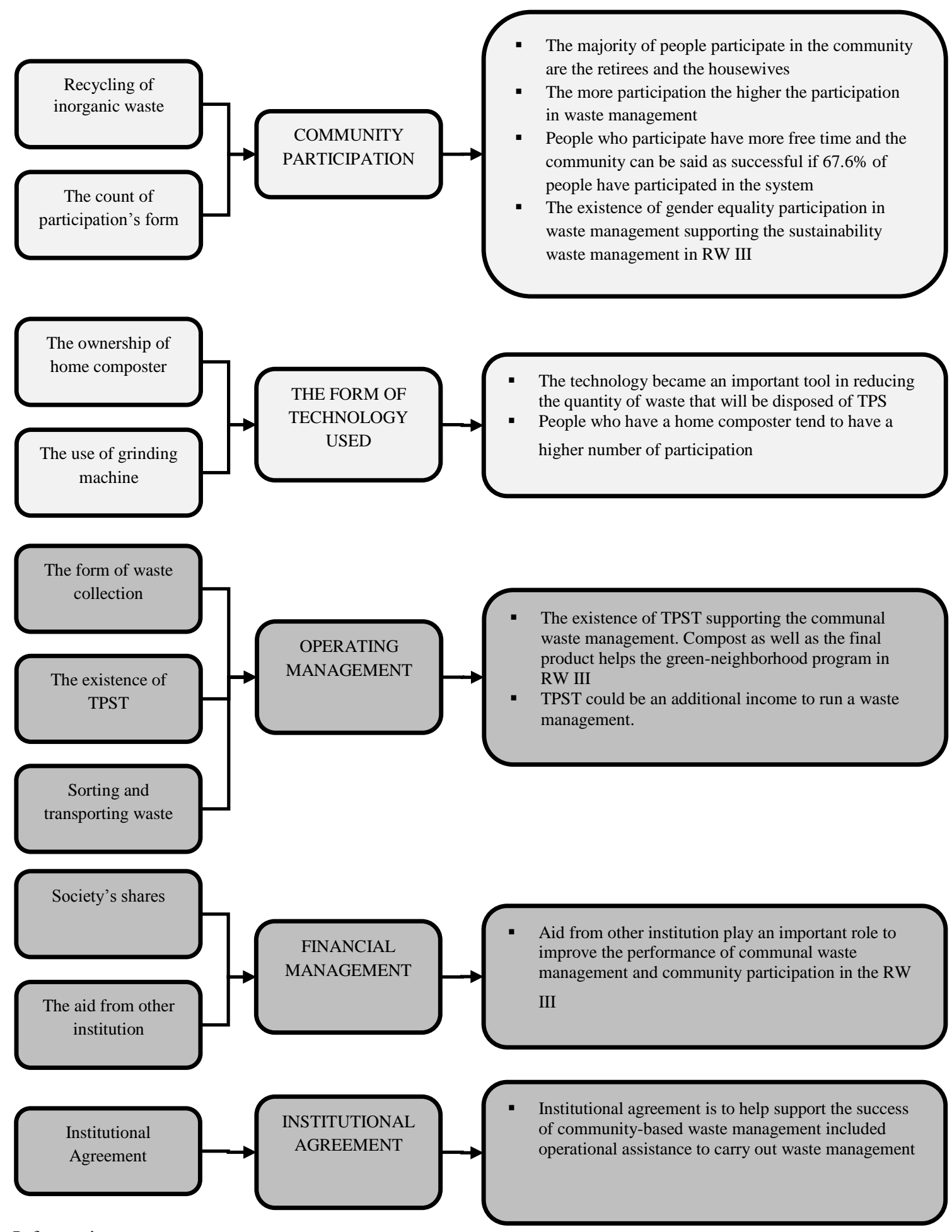

Information

: The main indicators of successful waste management in RW III

: Supporting indicators for successful waste management in RW III

Figure 1 Variables And Indicators Of Successful Waste Management in RW III, Rawajati 


\section{Glossaries}

RW : Rukun Warga, an administrative division in Indonesia, under the village

TPST : Tempat Pengelolaan Sampah Terpadu, Integrated waste management place, a place of communal composting ect.

TPS : Tempat Penampungan Sementara, a temporally waste collection place

3R : Reduce, reuse, and recycle

NGO : Non-Government Organization

\section{References}

ADB. 2005. Toward Sustainable Municipal Organic Waste Management in South Asia. Mandaluyong City

Gondokusumo, MadrimJoddy. 2005. Keberlanjutan Kawasan Kota: Persepektif Kemiskinan dan Lingkungan dalam Bunga Rampai Pembangunan Indonesia dalam Abad 21. hlm 402. URDI Publisher

Henningson, Stefan. 2001. Waste minimisation clubs: a cost-efficient policy instrument.. UK. European Environment.

Joseph, Kurian. 2005. Stakeholder Participation for Sustainable Waste Management. India. Elseveir

Kastaman, Roni. 2004. Pengelolaan Sampah Dari Hulu Ke Hilir. Depok. Jendela Aksara

Kidd, Sue.2005. The Environmental Dimension of Sustainable Regional Development in the English Regions: Reflections upon The Experience of North West England. England. Wiley Intersience.

Mohan, R. 2006. Sustainable Waste Management in The UK: The Public Health Role. Elseveir

Seniati, Liche. Discriminant Analysis, Statistik Lanjut Magister Profesi F.PSI. UI. University of Indonesia

Shekdar, Ashok.V.2008. Sustainable Solid Waste Management: An Integrated Approach for Asian Cities. India. Elseveir

Sivaranjani, V. 2000. Source Segregation and Door to Door Collection Of Msw. Solid Waste Management Division, Corporation of Chennai, Tamil Nadu, India

Widjaya,E.R.2011. Environmental and Economic Analyses Of Waste Disposal Options for Traditional Markets. Australia. Elseveir

Wu, Jianguo. 2008. Making the Case for Landscape Ecology An Effective Approach to Urban Sustainability. Landscape Journal 